doi: 10.18575/msrs.sm.e.17.18

UDC 616.37-002.1

COBISS.RS-ID 6835480

\title{
Impact of Biochemical Parameters in the Assessment of Local Complications and Outcome of Acute Pancreatitis
}

\begin{abstract}
Introduction: The mortality in severe acute pancreatitis is caused by sepsis and multiple organ failure. The disease is progressing from decade to decade, as shown by numerous international epidemiological reports. The mortality is higher after complications in addition to local and systemic defects, affecting the following organs: cardiovascular system, respiratory system, kidneys, central nervous system and metabolism in general.
\end{abstract}

Aim of the Study: To determine whether a low-cost and commonly used laboratory parameters (hematocrit and CRP), determined upon the admission of patients with acute pancreatitis in the intensive care unit can be predictors of necrosis of pancreatic tissue in a CT scan of the abdomen, and whether the trend of their values is the predictor of disease outcome.

Patients and Methods: This study was performed in patients $(n=61)$ who were treated for acute pancreatitis in the Intensive Care Unit at the University Clinical Center in Banja Luka, RS, General Hospital in Gradiska and Trebinje Hospital, from October, 2008 to October, 2013.

Results: The distribution of age exhibited an effect equal to the percentage of patients in the decade of 51.y.-60.y./ 61.y.-70.y., (20\%), that is, equal to the number of patients and in the decade of 31.y.-40.y. and over 71.y. The minimum number of patients who got sick was in the decade 21.y.-30.y. $10 \%$ of patients got sick in the decade 41.y.-50.y. The percentage of etiology determined cases was $64 \%$ and $36 \%$ was undetermined. Regarding the representation of the etiological factors, the most represented was biliary etiology (39\%), then $36 \%$ of the cases were idiopathic, alcoholism as etiological factor was represented in $23 \%$ of cases, and the etiology of post-operative acute pancreatitis in $2 \%$. CRP values on the admission to the ICU, higher than 150, and in accordance with the results of chi-square test, was shown to have been the predictor of the pancreatic tissue necrosis ch2 (1) $=13.97 p=.00$. Hct value upon the admission to the ICU, higher or equal to .45, and in accordance with the results of chi square test, was shown to have been the early predictor of necrosis: ch2 (1) $=4.21 p=.04$. According to the results of the logistic regression model, decrease in CRP and HCT values of $20 \%$ for at least 48 hours after the admission to the ICU, was not the predictor of disease outcome: B (SE) = 20:24 (23205.42); $p=.99 ;$ R2 (Negelkerke) $=.044$.

Conclusion: Low-cost laboratory tests in terms of hematocrit and CRP are simple, often used and available. According to the results of our study, we recommend them as a screening test when you are in doubt whether or not to send patients with acute pancreatitis on CT diagnostics although the trends of their values in the first 48 hours of treatment in an intensive care unit cannot be the predictor of outcome of disease.

Key words: acute pancreatitis, hematocrit, CRP

(Scr Med 2017:48:126-130)
Anita Đurđević Švraka ${ }^{1}$ Dragan Švraka ${ }^{2}$, Mirko Manojović, Petra Paovica ${ }^{3}$, Dragan Rakanović ${ }^{2}$

${ }^{1}$ PHI Hospital Gradiška ${ }^{2}$ University Clinical Center of Republic of Srpska

${ }^{3}$ General Hospital Trebinje

\section{Contact address:}

Anita Đurđević Švraka PHI Gradiška

$7840 o$ Gradiška Republic of Srpska

Bosnia and Herzegovina e-mail:

anita.djurdjevico@gmail.com phone number: +387-65-356-670
Submitted: May $8^{\text {th }}, 2017$ Accepted: June 13 ${ }^{\text {th }}, 2017$ 


\section{Introduction}

The mortality in severe acute pancreatitis is caused by sepsis and multiple organ failure. ${ }^{1}$ Mortality is likely to occur due to complications in addition to local and systemic damage affecting the following organs: cardiovascular system, respiratory system, kidney, central nervous system and metabolism in general.

The disease is progressing from decade to decade, according to numerous international epidemiological reports. In the UK, the incidence rate is $150-420$ cases per million inhabitants. ${ }^{1-5}$ In the Netherlands, there has been an increase in the incidence of $28 \%$ from the year $1985 .{ }^{3}$ Annual incidence of acute pancreatitis in Korea on 100000 residents increased from 15.6 (1995) to 19.4 (2000). One contributing factor to this growth is the increase in alcoholism abuse. ${ }^{4}$ The USA recorded the incidence of acute pancreatitis in 50-80 cases in 100000 residents per year. ${ }^{5}$

In 1984, Marseille launched a division of acute pancreatitis in the mild and severe forms of the disease. According to the Atlantic classification, severe acute pancreatitis is defined as acute pancreatitis with organ dysfunction, and the local or regional complications such as necrosis, abscess, pseudocyst. ${ }^{6}$ Acute pancreatitis starts being a self-ignition of the pancreas, and in 15-20\% of cases develops the heavy form, while a mild form of the disease, which includes interstitial edema in many reports, is in $80-85 \%$ of cases. ${ }^{7.8}$ The mortality rate is different in the reports from developed countries in relation to countries where the medical system is more modest. Basically, they all agree that all patients survive a mild form of the disease.

It is questionable when the patient should be placed in the intensive care unit, when to start with the resuscitation measures, whether to rely on the indications that recommend various wires and scoring systems or assess the severity of disease of each patient individually!? According to the British Guidelines (1998), indications for admission to the ICU are multiple fluid collections, pancreatic necrosis greater than 50\% or MODS. According to Santorini consensus (1999), the indications are overweight $\left(\mathrm{BMI}>30 \mathrm{~kg} / \mathrm{m}^{2}\right)$, Apache score 6 or $>6$ , CRP 150 g/dL. ${ }^{9}$

Main reasons for the admission of the patient to the ICU are aggressive volume resuscitation, adequate hemodynamic monitoring, central venous access, measurement of central venous pressure, intraabdominal pressure and arterial blood gases. Contrast CT diagnosis within 72 hours after the admission to the ICU was performed in all patients included in the study in order to assess the severity of disease.

\section{Aim of the Study}

The aim of our work was to determine whether low-cost and commonly used laboratory parameters (hematocrit and CRP), determined at the admission of patients with acute pancreatitis in the intensive care unit can be predictors of necrosis of pancreatic tissue in a CT scan of the abdomen, and whether the trend of their values is the predictor of disease outcome.

\section{Patients and Methods}

After obtaining the approval of the Ethics Committee of the University Clinical Center of Banja Luka RS, we conducted a retrospective, observational, multicenter study in 61 patients who were treated for acute pancreatitis in the Intensive Care Unit at the University Clinical Center in Banja Luka, RS, General Hospital in Gradiska and Trebinje Hospital. We analyzed the patients who were treated in intensive care units in the above mentioned health institutions due to acute pancreatitis, who met the parameters for inclusion in the study of the five-year period, from October 2008 to October 2013.

Factors for the inclusion in the study were determined laboratory parameters, C-reactive protein and hematocrit within $24 \mathrm{~h}$ and $48 \mathrm{~h}$ upon the admission to the ICU, and performed CT scan diagnostic (contrasting) within 72 hours after the admission.

Factors for the exclusion from the study were: patients younger than 18 years, patients admitted to the ICU after surgical interventions associated with acute pancreatitis, as well as patients with any form of cancer or acute exacerbation of chronic pancreatitis.

Statistical analysis was performed in the operating system SPSS $R$.

\section{Results}

Retrospective analysis of anamnesis of the patients treated in intensive care units of the above mentioned medical institutions in the five-year period showed that parameters for the inclusion in our analysis were fulfilled by 61 patients.

A five-year retrospective study of patients hospitalized in the ICU with a diagnosis of severe acute pancreatitis showed that the disease affects more women than men (65\% vs 35\%).

The distribution of age exhibited an effect equal to the percentage of patients in the decade of 51.y.-60.y./ 61.y.70.y., (20\%), that is, equal to the number of patients and in the decade of 31.y.-40.y. and over 71.y. The minimum 
number of patients was in the decade 21.y.-30.y. $10 \%$ of patients got sick in the decade 41.y.-50.y.

The percentage of etiology determined cases was $64 \%$ and $36 \%$ was undetermined. Regarding the representation of the etiological factors, the most represented was biliary etiology (39\%), 36\% of the cases were idiopathic, alcoholism as etiological factor was represented in $23 \%$ of cases, and the etiology of post-operative acute pancreatitis in $2 \%$.

In the analyzed group, 16 patients died (26.2\%). The mortality compared to the CT findings determined upon the admission of the patient to the ICU was the highest among the initial necrosis CT contrast scan findings (Table 1).

Table 1. Mortality in Relation to CT Findings

\begin{tabular}{cccc}
\hline Initial CT abdomen & & Frequency & Percentage \\
\cline { 2 - 3 } Pancreas edema & Survived & 21 & 84.0 \\
& Died & 4 & 16.0 \\
& Total & 25 & 100.0 \\
Pancreas necrosis & Survived & 15 & 55.6 \\
& Died & 12 & 44.4 \\
Formed pancreatic & Total & 27 & 100.0 \\
pseudlocyst & Survived & 5 & 100.0 \\
Normal CT scan & Survived & 4 & 100.0 \\
\hline
\end{tabular}

According to the chi square test results, Hct value upon the admission to the ICU, higher or equal to .45, was the predictor of an indication of early necrosis: $\chi 2(1)=4.21$ The; $\mathrm{p}=.04$. The level of effect, expressed through the "odds ratio" statistics was 3.4. Therefore, patients with elevated Hct value upon the admission were 3.4 times more likely to present necrosis pancreatic tissues in CT findings in 72 hours after the admission, compared to patients who did not present elevated Hct value.

According to the chi-square test results, CRP values on the admission to the ICU, higher than 150, was the predictor for pancreatic tissue necrosis displayed on CT findings 72 hours after the admission to the ICU: $\chi 2$ (1) $=13.97 ; \mathrm{p}=.00$. The level of effect, expressed through the "odds ratio" statistics was 8.63. Therefore, patients with the CRP level higher than 150, were 8.63 times more likely to present necrosis pancreatic tissues in CT findings in 72 hours after the admission, compared to patients who did not have elevated CRP.

According to the results of the logistic regression model, decrease in CRP and HCT values of $20 \%$, for at least 48 hours after the admission to the ICU, was not the predictor of the disease outcome: B (SE) = 20:24 (23205.42); $\mathrm{p}=$ .99; R2 (Negelkerke) $=.044$. Therefore, based on the decrease of CRP and HCT, it was not possible to reliably predict the outcome.

\section{Discussion}

According to the recommendations of the UK guidelines for the management of acute pancreatitis, level B recommendation says that idiopathic cases should be within $20 \%$ of the AP, ${ }^{5}$ whereas in our study, the number of idiopathic cases was $36 \%$. The authors note the importance of scoring systems such as Ranson score, Apache II, Glasgow score etc. as relevant tools in the prognosis of the disease, but which also confirm the fact that only one biochemical parameter can be an indicator of early stratification of AP weights when followed more than 24 hours upon the admission. ${ }^{10}$

Among individual biochemical parameters, CRP value is the most used one. Values greater than $150 \mathrm{mg} / \mathrm{L}$ indicate complications of acute pancreatitis. ${ }^{10}$ Since the CRP protein of the acute phase is not specific for acute pancreatitis, it is necessary to exclude other inflammatory conditions. Gamatos et all. argue that CRP may not be an indicator of necrosis, but serial measurements after 24 hours may indicate the development of local complications. ${ }^{11}$ In our case, the value of CRP higher than $150 \mathrm{mg} / \mathrm{L}$ in patients who had been admitted to the ICU was the predictor of early necrosis.

Acute pancreatitis, particularly more severe forms, leads to the extravasation of fluid into the third space, and create a haemoconcentration. Hematocrit, as one of the simple predictive parameter, can be determined for the presence of necrosis and dysfunction of organs. In some studies that monitored the value of Hct $>44 \%$ for men and $>40 \%$ for women, it has not proven as the predictor for weight of acute pancreatitis, and therefore for necrosis, but it is said that the cause of this result was the high incidence of mild forms of the disease in the sample. ${ }^{12,13}$ Taking into consideration that our study included only patients with severe AP, CRP over $150 \mathrm{mg} / \mathrm{L}$ and hematocrit $>0,42 \%$ for both sexes proved to have been predictors of necrosis.

Severe pancreatitis carries a higher mortality. In our sample, mortality was $44.4 \%$ in patients with necrosis on the initial CT findings. In other studies, the mortality was about $20 \%^{14,15}$ while the recommendations of the UK guidelines for the management of acute pancreatitis state 
that mortality should be up to $30 \%$ in relation to the severe form of the disease. The reasons for the high mortality in our conditions may be a late occurrence of the patient in a medical facility where the acute pancreatitis would be recognized, diagnosed and treated appropriately and on time.

An adequate treatment should disable the progression of disease, MODS and sepsis. We followed the trend of decrease of CRP and hematocrit $48 \mathrm{~h}$ after the admission of our patients to the ICU, but the statistical data indicate that, according to the results of the logistic regression, the decrease of CRP and HCT of $20 \%$ for at least 48 hours after the admission to the ICU, were not predictors of disease outcome.

\section{Conclusion}

Despite the development of modern medicine, we are not always able to do an invasive diagnostic procedure because they are not always available, and a general condition of patients treated for acute pancreatitis complicates their transport to diagnostic procedures. Low-cost laboratory tests in terms of hematocrit and CRP are simple, often used and available. According to the results of our study, we recommend them as a screening test when you are in doubt whether or not to send patients with acute pancreatitis on CT diagnostics although the trends of their values in the first 48 hours of treatment in an intensive care unit cannot be the predictor of outcome of disease. New prospective studies may indicate whether the trend of hematocrit and CRP in the course of treatment may indicate the exact and proper moment to do CT diagnostics.

\section{Reference}

1. Yousaf M., McCallion K., Diamond T. Menagment of severe acute pancreatitis. Br J Surg, 2003.; 90:407-20.

https://doi.org/10.1002/bjs.4179

PMid:12673741

2. Goldacre M.J., Roberts S.E. Hospital admission for acute pancreatitis in a English population, 196398: database study of incidence and mortality. BMJ 2004.;328(7454):1466-1469 https://doi.org/10.1136/ bmj.328.7454.1466PMid:15205290 PMCid:PMC428514

3. Eland I.A., Sturkenboom M.J.C.M., Wilson J.H.P., Stricker B.H.Ch. Incidence and Mortality of Acute Pancreatitis between 1985-1995. Scandinavian Journal of Gastroenterology.2000. Vol.35, No. 10, 1110-116. https://doi.org/10.1080/003655200451261 PMid:11099067

4. Kim CD. Current status of acute pancreatitis in Korea. Korean Journal of Gastroenterology, 2003. 42(1):1-11. PMid:14532725
5. UK guidelines for the menagement of acute pancreatitis. Gut 2005.; 54;1-9. PMid:15591495

6. Bollen T.L. et all. The Atlanta Classification of acute pancreatitis revisited. Pancreas 2006.; 33:448-449. https://doi.org/10.1097/00006676-200611000-00045 https://doi.org/10.1097/00006676-200611000-00044 https://doi.org/10.1097/00006676-200611000-00047 https://doi.org/10.1097/00006676-200611000-00046

7. Simon P.Young, Jonathan Thompson. Severe acute pancreatitis. Contin Educ Anaesth Crit Care Pain, 2008.,8(4):125-128. https://doi.org/10.1093/bjaceaccp/mkno2o

8. George H. Sakorafas, Christos Lappas, Aikaterini Mastoraki, Spiros G.Delis,Michael Safioleas. Infectious Disorders-Drug Targets 2010., 10, 9-14. https://doi.org/10.2174/187152610790410936 PMid:20180753

9. Dervenis C, Johnson CD, Bassi C, Bradley EL, Imrie CW, McMahon MJ, Modlin I. Diagnosis, objective assessment of severity and management of acute pancreatitis. The Santorini Consensus Conference. Int J Pancreatol 1999; 25:195210. [99382793]

PMid:10453421

10. Khanna A.K.,et all. Comparison of Ranson,Glasgow, MOSS, SIRS, BISAP, APACHE II, CTSI scores IL-6, CRP, and Procalcitonin in Predicting Severity, Organ Failure, Pancreatic Necrosis, and Mortality in Acute Pancreatitis. Hiddawi Publishing Corporation. HPB Srgery, Volume 2013, Article ID 367581, 10 pages.

11. Gomatos I.P. et all. Prognostic markers in acute pancreatitis. NIHR Pancreas Research Unit,Liverpool. Expert review of Molecular diagnostics.14(3),333-346 (2014).

https://doi.org/10.1586/14737159.2014.897608 PMid:24649820

12. Remes-Troche Jose M. Et all. Hemocontrentration is poor predictor of severity in acute pancreatitis. World $\mathrm{J}$ of Gastroenterology 2005:11(44):7018-7023. https://doi.org/10.3748/wjg.v11.i44.7018 PMid:16437609 PMCid:PMC4717047

13. Brown A., et all. Hemocontrentation is an early marker for organ failure and necrotizing pancreatitis. Pancreas (2000.). Vol.20,No.4, pp.367-372.

14. Banks PA. Infected necrosis: morbidity and therapeutic consequences. Hepatogastroenterology. 1991;38:116-119. [PubMed] PMid:1855766

15. Büchler MW, Gloor B, Müller CA, Friess H, Seiler CA, Uhl W. Acute necrotizing pancreatitis: treatment strategy according to the status of infection. Ann Surg. 2000;232:619-626. https://doi.org/10.1097/00ooo658-200011000-00001 PMid:11066131 PMCid:PMC1421214 


\section{Značaj biohemijskih parametara u procjeni lokalnih komplikacija i prognoze akutnog pankreatitisa}

\section{SAŽETAK}

Uvod: Mortalitet u teškom akutnom pankreatitisu nastaje zbog sepse i višestrukog zatajenja organa. Bolest je u progresiji iz decenije u deceniju što pokazuju brojni svjetski epidemiološki izvještaji. Letalitet je izgledan nakon komplikacija koje pored lokalnih oštećenja, zahvataju i sistemske organe: kardiovaskularni sistem, respiratorni sistem, bubrege, centralni nervni sistem i metabolizam u cjelini

Cilj rada: Utvrditi da li jeftini i često korišteni laboratorijski parametri (Hct i CRP), određeni pri prijemu bolesnika sa akutnim pankreatitisom u jedinicu intenzivnog liječenja mogu da budu prediktori nekroze tkiva pankreasa na CT-u abdomena, te da li je trend njihovih vrijednosti prediktor ishoda bolesti.

Ispitanici i metode: Ova studija rađena je kod 61 ispitanika koji su liječeni zbog akutnog pankreatitisa u Jedinicama intenzivnog liječenja u Univerzitetskom Kliničkom centru RS u Banjoj Luci, bolnici u Gradišci i bolnici u Trebinju od oktobra 2008. do oktobra 2013. godine.

Rezultati: Distribucija prema starosti pokazuje jednak procenat pacijenata u decenijama od 51.g.-60.g./ 61.g.-70.g., (20\%), odn. jednak broj pacijenata je i u deceniji od 31.g.-40.g. i preko 71.g. Najmanji broj pacijenata je u deceniji 21.g.-30.g. 10\% pacijenata oboljeva u deceniji 41.g.-50.g. Postotak etiološki utvrđenih slučajeva je 64\%, odnosno neutvrđenih 36\%. Kada je riječ o zastupljenosti etioloških faktora, najviše je zastupljena bilijarna etiologija (39\%), zatim 36\% su idiopatski slučajevi, alkohol kao etiološki faktor je zastupljen 23\%, a 2\% je akutni pankreatitis postoperativne etiologije. CRP vrijednost, viša od 150 na prijemu u ICU, a u skladu sa rezultatima hi-kvadrat testa, pokazala se kao rani prediktor nekroze tkiva pankresa: ch2 (1) = 13.97 $p=.00$. Hct vrijednost po prijemu na intenzivnu njegu, koja je veća ili jednaka 0.45 , a pozivajući se na hi kvadrat test, pokazala se kao rani prediktor nekroze: ch2 (1) = $4.21 \mathrm{p}=.04$. Smanjenje CRP i HCT za 20\% vrijednosti u odnosu na inicijalne, a u roku od 48 sati nakon prijema u JIL, prema rezultatima po modelu logističke regresije nije prediktor ishoda bolesti: $\mathrm{B}$ (SE) = 20:24 (23205.42); $p=.99 ; \mathrm{R} 2$ (Negelkerke) $=.044$.

Zaključak: Jeftini laboratorijski testovi u smislu Hct i CRP su jednostavni, često korišteni i dostupni. Prema rezultatima naše studije možemo in preporučiti kao skrining testove kada smo u nedoumici da li poslati pacijente sa akutnim pankreatitisom na CT dijagnostiku, iako trend njihovih vrijednosti u prvih 48 sati terapije u jedinicama intenzivnog liječenja ne može biti prediktor ishoda bolesti.

Ključne riječi: akutni pankreatitis, Hct , CRP 